\title{
Monitoring of Total Suspended Solid in Coastal Waters due to Conventional Gold Mining Using Multi Temporal Satellite Data, Case Study: Bombana, Southeast Sulawesi
}

Nurgiantoro $^{1}$ and Lalu Muhamad Jaelani ${ }^{1}$

\begin{abstract}
Coastal area is an area of transition from terrestrial to marine ecosystems. This area is generally suffered by human, including gold mining activities. The existence of gold in Bombana discovered 2008, making the region as the center of public attention. The appearance of a gold mine in this region other than a blessing, but also brought new problems, especially in coastal areas. Therefore, a routine monitoring is needed to maintain environmental sustainability. Total Suspended Solid (TSS) is one of parameters that are often used for waters quality monitoring. In this research multi-temporal Landsat 8 (2013 to 2015) and in-situ measurement (November 20, 2015) were used to estimate the distribution of TSS. From the analysis, the concentration of TSS in 2014 decreased by $2.88 \%(36.97 \mathrm{~g} / \mathrm{m3})$ and increased by $6.76 \%(81.64 \mathrm{~g} / \mathrm{m3})$ in 2015 . The results showed that all estimated-TSS overestimated the permissible water quality threshold (TSS $\leq 80 \mathrm{~g} / \mathrm{m} 3$ ), it could be concluded that the gold mining activities in this area has decreased coastal ecological quality.
\end{abstract}

Keywords-Coastal waters, Gold mining, Landsat, Monitoring, TSS.

\section{INTRODUCTION}

The existence of gold mines often become the public's attention. Gold mining is a blessing, but also brought new problems to environment [1]. As it is known that the coastal region is an area of transition between terrestrial and marine ecosystems are affected by changes in land and sea. Besides having great potential, the coastal region is also an ecosystem that is affected by human activities [2]. Environmental damage is a serious threat, considering the mining activities are inherently destructive because changing the landscape, physical and chemical properties of soil, both on land and in coastal waters [3]. The concentration of TSS can be use as indication of water ecological condition. Its high concentration in ecosystem creates a high risk to aquatic life that receive tailings in the lowlands. At the excessive amount it became harmful to the lives and could lead to significant ecological damage [4].

To monitor the significant changes on ecology, remote sensing is a reliable method as well as in-situ measurement on the field [5]. The main purpose of this study was to monitor the spatial distribution of TSS concentration in the coastal waters of Bombana (2013 to 2015).
${ }^{1}$ Nurgiantoro and Lalu Muhamad Jaelani are with Department of Geomatics Engineering, Institut Teknologi Sepuluh Nopember,

\section{METHOD}

A. Study Area

Location of research sites in Southeast Sulawesi, precisely in the area of coastal waters Bombana. Geographically located between $122.05^{\circ}$ to $122.09^{\circ} \mathrm{E}$ and $-04.54^{\circ}$ to $-04.63^{\circ} \mathrm{N}$. The location of study area were shown in Figure 1.

B. Data Collection

A multi-temporal Landsat 8 data (2013 to 2015) at Path/Row of $113 / 063$ and in-situ data of TSS concentration were collected on November 20, 2015 (Table 1). Imagery Landsat data obtained from ordering through https://espa.cr.usgs.gov. Meanwhile, the in-situ data of seawater samples collected by 5 points at the acquisition date Landsat. Furthermore, the five samples are processed in the laboratory for analysis purposes TSS concentration

\section{Atmospheric Correction}

The purpose of atmospheric correction is to reduce the total reflectance of objects Top of Atmosphere (ToA) radiance to the lighting conditions and the elimination of atmospheric effects. Generally, reflectance satellite recorded at each wavelength, is determined by the reflection of the physical components with different processes [5]. There are many methods for removing the effects of the atmosphere, but that is often recommended is to use a web-based $6 \mathrm{~S}$ atmospheric code in http://6s.ltdri.org/ [6]. Special on Landsat satellite, the image that has been corrected. Product surface reflectance (sr) LDCM and ETM+ is freely accessible without charge and can be obtained by ordering at https://espa.cr.usgs.gov. however, the product is still in need of a scale factor to get value of remote sensing reflectance $(\operatorname{Rrs}(\lambda))$ actually. The equation for calculating the $\operatorname{Rrs}(\lambda)$ Landsat is as follows:

$R_{r s}(\lambda)=\frac{\text { srBand }_{-} X}{10000 \pi}$

where: $\operatorname{Rrs}(\lambda)$ is remote sensing reflectance, srBand_X is surface reflectance band $\mathrm{X},(\mathrm{X}=$ band 1 to band 7$)$, and $10000 \pi$ is a scaling factor.

In this research, atmospheric correction is performed only on the visible band using processed products that have been available on the product Landsat when an order for the image, so that the image obtained from the reservation is the image that has been corrected on the atmosphere and ready for various analyzes. While the TSS algorithm modeling analysis in this research uses only $\operatorname{Rrs}\left(\lambda_{2}\right), \operatorname{Rrs}\left(\lambda_{3}\right)$, and $\operatorname{Rrs}\left(\lambda_{4}\right)$. The use of the band with a

Surabaya, Indonesia. E-mail: noergiantoro@yahoo.co.id; lmjaelani@geodesy.its.ac.id. 
wavelength of $450-670 \mathrm{~nm}$ is based on the theory that has been developed. thus, based on the optical properties of the waters are divided into two, namely waters which its optical properties are dominated by phytoplankton and waters which its optical properties are dominated by materials suspended.

The waters of which its optical properties are dominated by phytoplankton, the percentage of spectral reflectance at a wavelength of $450-510 \mathrm{~nm}$ will be even lower if the higher concentration of chlorophyll. It shows that chlorophyll has a high absorption power of the wavelength of the blue band. At a wavelength of 640-670 $\mathrm{nm}$, the higher the concentration of chlorophyll, the higher the percentage of the reflection.

While in waters dominated by the optical properties of suspended materials showed the opposite, ie at a wavelength of 450-510 $\mathrm{nm}$ reflectance values increasing in line with increasing concentrations of TSS. The existence of TSS can absorb and reflect radiation spectrum of visible light that penetrates below the surface of the water, but the effect is more in the nature as a manifestation of backscattering exposing turbid water. it would also generate large reflectance difference on the entire range of wavelengths of visible light and smaller at shorter wavelengths due to the absorption by chlorophyll [7].

\section{Regression}

Developing empirical algorithms using regression algorithm from measured-TSS concentration as well as single-band and two-band ratios of $\operatorname{Rrs}(\lambda)$ [8]. The regression model follow the equation:

$y=a x+b$

Where, $y$ is the in-situ TSS concentration, $x$ is the value of $\operatorname{Rrs}(\lambda), a$ is the slope of regression line, and $b$ is the $y$ intercept. To find the value of $a$ and $b$ were used least square method.

The estimated- TSS concentration from Landsat 8 data was performed by developed algorithms from in-situ data (Table 3). With the highest determination coefficient $\left(R^{2}\right.$ $>0.5)$.

\section{RESULTS AND DISCUSSION}

The analysis TSS algorithm was developed from twoband ratio between $\lambda_{3}$ and $\lambda_{2}$ with coefficient of determination $R^{2}=0.569$ (Table 2). The empirical algorithm was shown in Figure 2 and Equation 3, as follow:

$\mathrm{TSS}=1384.73824 *\left(\frac{R_{r S}\left(\lambda_{3}\right)}{R_{r S}\left(\lambda_{2}\right)}\right)-601.56333$

Based on the above algorithm, TSS concentrations in coastal waters Bombana in each year (2013 to 2015), was observed to decline $2.88 \%$ in $2014\left(36.97 \mathrm{~g} / \mathrm{m}^{3}\right)$. TSS concentrations decline was due to a moratorium on mining activities until the end of 2014 and began to operate again in the year 2015. With a back operation in the year resulted in the concentration of TSS increased to $6.76 \%$ in $2015\left(81.64 \mathrm{~g} / \mathrm{m}^{3}\right)$. whereas the Table 4 shows The average TSS was $1241.13 \mathrm{~g} / \mathrm{m}^{3}, 1204.16 \mathrm{~g} / \mathrm{m}^{3}$, and $1285.80 \mathrm{~g} / \mathrm{m}^{3}$; for the data of 2013, 2014, and 2015; respectively.

Based on the Ministry of the Environment No. 51 of 2004 on Sea Water Quality Standard. The quality standard for marine tourism TSS is $80 \mathrm{~g} / \mathrm{m}^{3}$, whereas the quality standards for marine TSS divided into three categories including: $20 \mathrm{~g} / \mathrm{m}^{3}$ for coral, $80 \mathrm{~g} / \mathrm{m}^{3}$ for the mangrove, and $20 \mathrm{~g} / \mathrm{m}^{3}$ for seagrass. From the above information, can be sure that the TSS concentrations in coastal waters Bombana has significantly exceeded the value of the standard quality, good sea water quality standard for marine tourism and marine water quality standard for marine biota.

Monitoring of the TSS based on its concentration, indicating that the direction of the distribution of TSS heading north along the coast Bombana. While on the southern coast identified fewer. If seen spreading and connecting with the position of the observation station, the river estuary Identified receive the greatest TSS is at station 2 to station 4 (Figure 3), this happens because the river flow is exactly the gold miners panning. According to their characteristics, river water flows from upstream to downstream (estuary) brings a wide range of material, either in the form of suspended solids as physical parameters, as well as the elements and chemical compounds. A large number of material of some of these parameters depending on the condition of the river upstream and will be brought up to the mouth of a burden on coastal waters.

\section{CONCLUSION}

The measurment data shows that the concentration of TSS exceeded the threshold of permissible TSS concentration following Decree of the Ministry of Environment No. 51 of 2004 (TSS $\leq 80 \mathrm{~g} / \mathrm{m}^{3}$ ). Thus, the coastal waters of Bombana has been affected by gold mining activities.

\section{ACKNOWLEDGEMENT}

This research is mandatory and a requisite for completing studies at the Graduate Program. The first author was supported by DIKTI scholarship, Ministry of Research, Technology and Higher Education of the Republic of Indonesia. In-situ data obtained from independent measurements and test results from the Forensic and Biomolecular Laboratory, Faculty of Mathematics and Natural Sciences, Haluoleo University. While the multi-temporal Landsat image data ordered via EROS Science Processing Architecture (ESPA). the author would also like to thank all parties concerned by this research. 

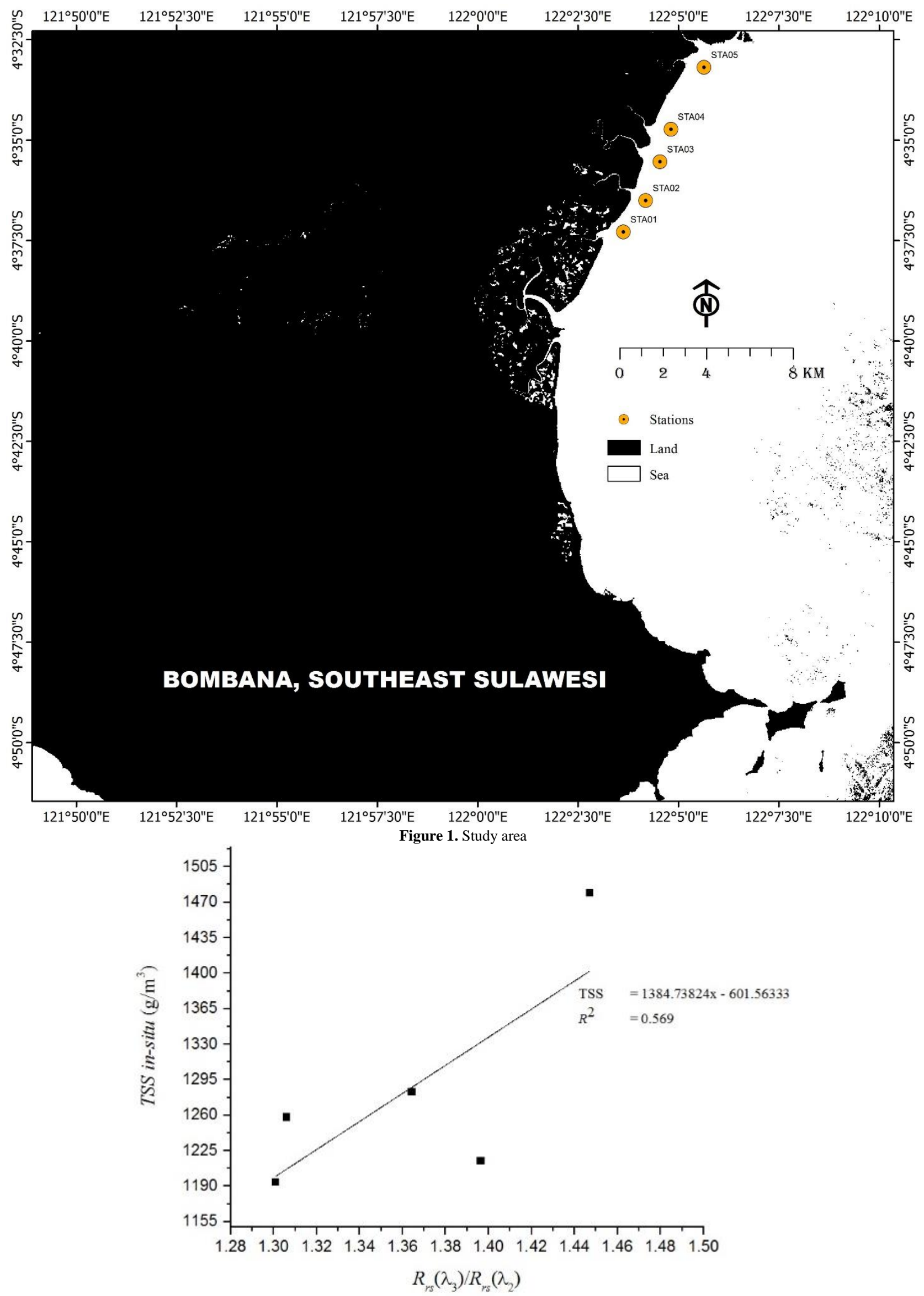

Figure 2. Linier regression algorithm for TSS estimation with independent variable of band-ratio of $\operatorname{Rrs}\left(\lambda_{3}\right) / \operatorname{Rrs}\left(\lambda_{2}\right)$ 
August $2^{\text {nd }}$ 2016, Postgraduate Program Institut Teknologi Sepuluh Nopember, Surabaya, Indonesia

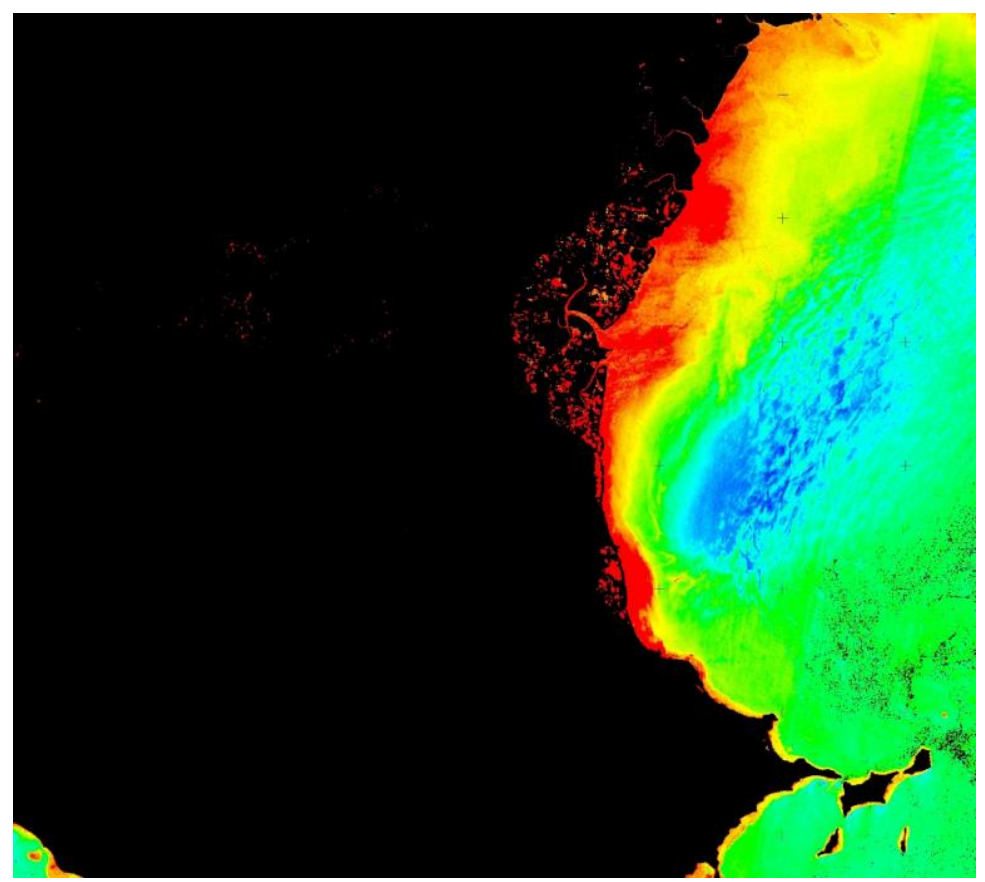

TSS $[\mathrm{g} / \mathrm{m} 3]$

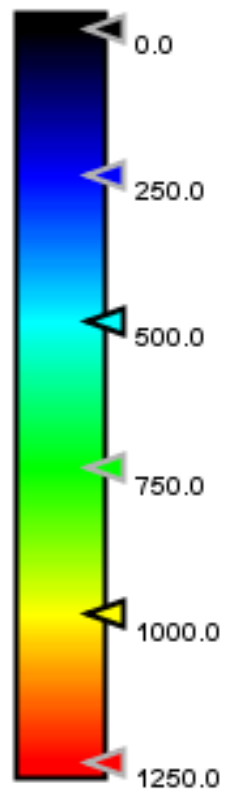

a).

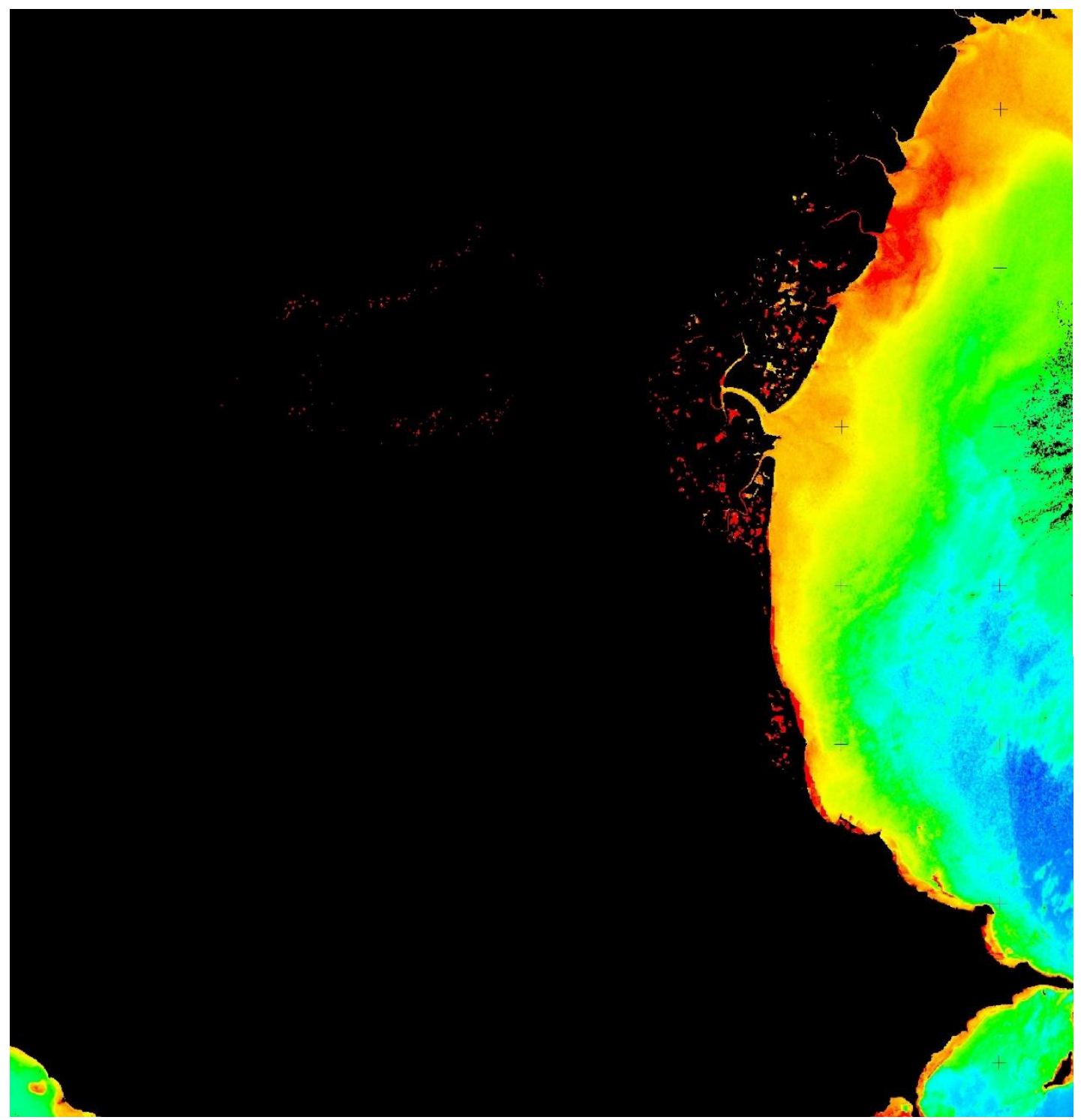

TSS $[g / \mathrm{m} 3]$

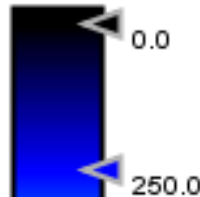

b). 


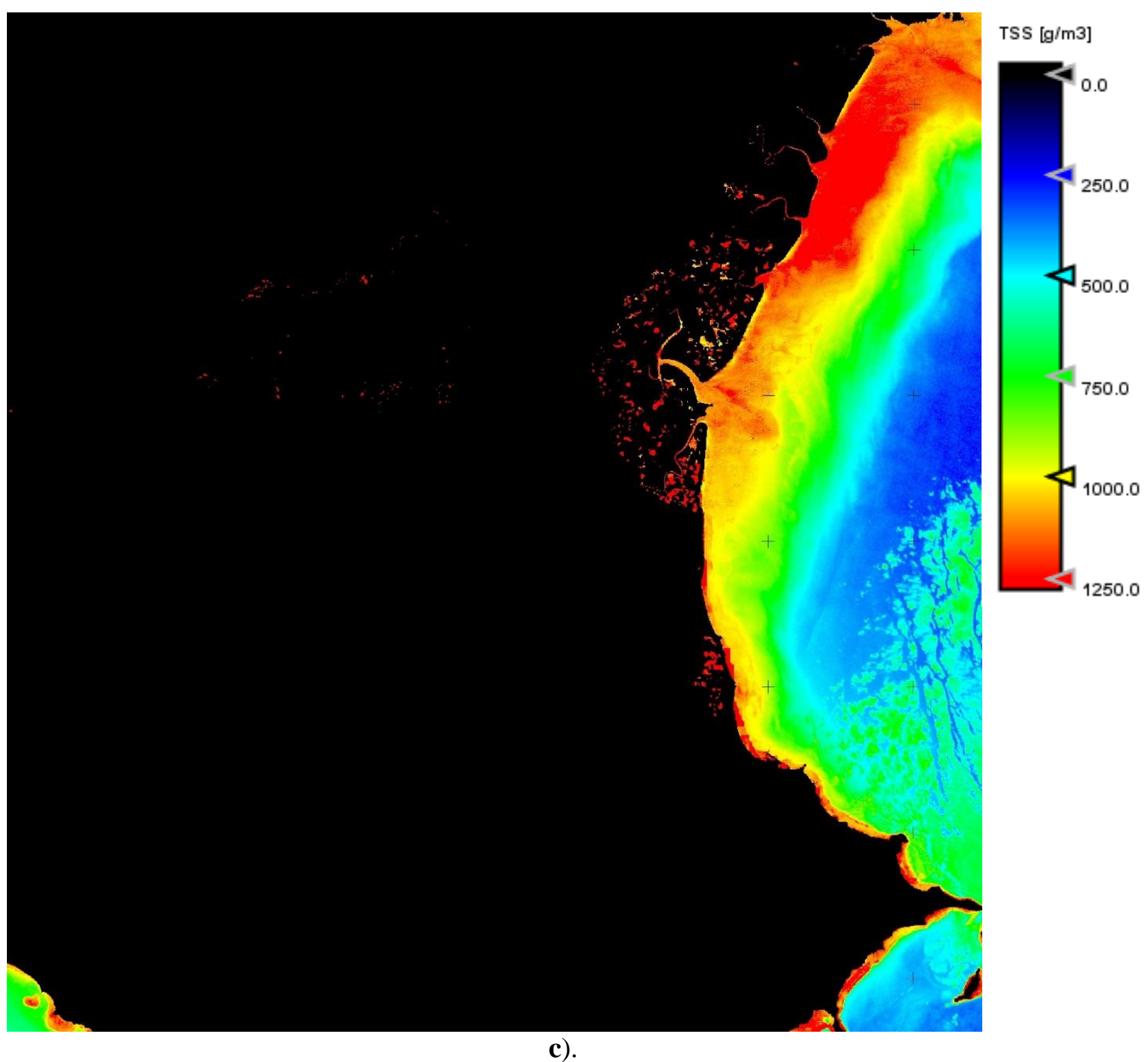

Figure 3. Distribution Map of TSS Concentration from Landsat 8: a). November 2015, b). November 2014, c). November 2013

TABLE 1 .

IN-SITU TSS CONCENTRATION

\begin{tabular}{lcccc}
\hline \hline \multirow{2}{*}{ Stations } & \multirow{2}{*}{$\begin{array}{c}\text { Local Time } \\
(\text { GMT+8 })\end{array}$} & TSS & \multicolumn{2}{c}{ Coordinate } \\
\cline { 3 - 5 } & & $\left(\mathrm{g} / \mathrm{m}^{3}\right)$ & $\left(^{\circ}\right)$ & $\left(^{\circ}\right)$ \\
\hline STA01 & $09: 12: 52$ & 1258 & 122.06053 & -4.62137 \\
STA02 & $09: 26: 20$ & 1215 & 122.06978 & -4.60826 \\
STA03 & $09: 42: 36$ & 1479 & 122.07568 & -4.59216 \\
STA04 & $09: 50: 32$ & 1283 & 122.08019 & -4.57874 \\
STA05 & $10: 06: 06$ & 1194 & 122.09396 & -4.55307 \\
\hline \hline
\end{tabular}


TABLE 2.

LANDSAT 8 REMOTE SENSING REFLECTANCE

\begin{tabular}{cccccccc}
\hline \hline \multirow{2}{*}{ Station } & \multicolumn{7}{c}{$R_{r s}\left(\mathrm{sr}^{1}\right)$} \\
\cline { 2 - 8 } & $\lambda_{1}$ & $\lambda_{2}$ & $\lambda_{3}$ & $\lambda_{4}$ & $\lambda_{5}$ & $\lambda_{6}$ & $\lambda_{7}$ \\
\hline STA01 & 0.01846 & 0.02186 & 0.02856 & 0.02252 & 0.00939 & 0.00671 & 0.00525 \\
STA02 & 0.01829 & 0.02187 & 0.03054 & 0.02668 & 0.00983 & 0.00641 & 0.00497 \\
STA03 & 0.01634 & 0.01981 & 0.02867 & 0.02487 & 0.00689 & 0.00330 & 0.00246 \\
STA04 & 0.02346 & 0.02798 & 0.03818 & 0.03141 & 0.01682 & 0.01415 & 0.01158 \\
STA05 & 0.02267 & 0.02689 & 0.03498 & 0.03122 & 0.01879 & 0.01562 & 0.01273 \\
\hline \hline
\end{tabular}

TABLE 3.

SINGLE BAND-BASED AND TWO BAND RATIO REGRESSION ALGORITHM FOR TSS WITH $R^{2}$

\begin{tabular}{|c|c|c|c|c|c|c|}
\hline Single Band & $\lambda_{2}$ & $\lambda_{3}$ & $\lambda_{4}$ & & & \\
\hline$y=a x+b$ & 0.29526 & 0.14554 & 0.13919 & & & \\
\hline$y=a \log (x)+b$ & 0.33040 & 0.16039 & 0.13046 & & & \\
\hline Two Band Ratio & $\lambda_{2}, \lambda_{3}$ & $\lambda_{2}, \lambda_{4}$ & $\lambda_{3}, \lambda_{2}$ & $\lambda_{3}, \lambda_{4}$ & $\lambda_{4}, \lambda_{2}$ & $\lambda_{4}, \lambda_{3}$ \\
\hline$y=a(x i / x j)+b$ & 0.54739 & 0.16747 & 0.56887 & 0.00004 & 0.19794 & 0.00050 \\
\hline$y=a \log (x i / x j)+b$ & 0.55810 & 0.18232 & 0.55810 & 0.00021 & 0.18232 & 0.00021 \\
\hline $\mathrm{y}=\mathrm{a}(\log (\mathrm{xi}) / \log (\mathrm{xj}))+\mathrm{b}$ & 0.45138 & 0.15271 & 0.44548 & 0.00034 & 0.14591 & 0.00046 \\
\hline
\end{tabular}

TABLE 4.

COMPARISON BETWEEN MEASURED AND ESTIMATED TSS

\begin{tabular}{|c|c|c|c|c|c|}
\hline \multirow{3}{*}{ Station } & \multicolumn{4}{|c|}{$\mathrm{TSS}\left(\mathrm{g} / \mathrm{m}^{3}\right)$} & \multirow{3}{*}{ Quality Standards } \\
\hline & \multirow{2}{*}{$\begin{array}{c}\text { In-situ } \\
2015\end{array}$} & \multicolumn{3}{|c|}{ Estimated } & \\
\hline & & 2015 & 2014 & 2013 & \\
\hline STA01 & 1258 & 1206.97 & 1186.69 & 1260.06 & \\
\hline STA02 & 1215 & 1332.01 & 1274.15 & 1352.53 & \\
\hline STA03 & 1479 & 1402.38 & 1213.77 & 1219.42 & $20-80 \mathrm{~g} / \mathrm{m}^{3}$ \\
\hline STA04 & 1283 & 1287.75 & 1202.57 & 1205.46 & \\
\hline STA05 & 1194 & 1199.89 & 1143.60 & 1168.16 & \\
\hline
\end{tabular}

\section{REFERENCES}

[1] A. Hafid, "Konflik Sara di Wilayah Pertambangan, Kasus Sulawesi Tenggara,". Kongres Kebudayaan Indonesia (Oktober). pp. 1-12, 2013.

[2] R. Dahuri, "Coastal zone management and transmigration in Indonesia, paper presented at international workshop - Integrated Coastal Management in Tropical Developing Countries: Lessons Learned from Successes and Failures, May 24- 28, Xiamen,People's Republic of Chin," p. 16pp, 1996.

[3] M. Ahyani, "Pengaruh Kegiatan Penambangan Emas Terhadap Kondisi Kerusakan Tanah Pada Wilayah Pertambangan Rakyat di Bombana Provinsi Sulawesi Tenggara," Semarang, UNDIP, 2011.

[4] N. Laili, F. Arafah, L. M. Jaelani, L. Subehi, A. Pamungkas, E. S. Koenhardono, and A. Sulisetyono, "Development of Water Quality Parameter Retrieval Algorithms for Estimating Total Suspended Solids and Chlorophyll-a Concentration using Landsat-8 Imagery at Poteran Island Water," vol. II, no. October, pp. 28-30, 2015.

[5] H. R. Gordon and M. Wang, "Retrieval of water-leaving radiance and aerosol optical thickness over the oceans with SeaWiFS: a preliminary algorithm.," Appl. Opt., vol. 33, no. 3, pp. 443-452, 1994.

[6] E. Vermote, D. Tanre, J. L. Deuze, M. Herman, and J. J. Morcrette, "Second Simulation of the Satellite Signal in the Solar Spectrum (6S). 6S User Guide Version 2. Appendix III: Description of the subroutines," vol. 35, no. 3, pp. 675-686, 1997.
[7] I. S. Robinson, Satellite oceanography: An introduction for oceanographers and remote sensing scientists. England: Chiester, 1985.

[8] R. Aguirre-Gomez, "Detection of Total Suspended Sediments in the North Sea using AVHRR and Ship Data," Int. J. Remote Sens., vol. 21 , no. 8, pp. 1583-1596, 2000 